\title{
A REFLEXÃo, POR PARTE DE UMA PROFESSORA DE LÍNGUA PORTUGUESA, SOBRE SEU ENSINO DA PRODUÇÃO TEXTUAL
}

\author{
THE PORTUGUESE LANGUAGE TEACHER'S REFLECTION \\ ON HER TEACHING OF TEXTUAL PRODUCTION
}

\begin{abstract}
Elaine Cristina Nascimento da Silva | Lattes | elainecrisufrpe@gmail.com Universidade Federal do Agreste de Pernambuco
\end{abstract}

Lívia Suassuna | Lattes | livia.suassuna@ufpe.br

Universidade Federal de Pernambuco

Resumo: Nesta pesquisa, investigamos a reflexão de uma professora sobre seu ensino da produção textual. O sujeito da pesquisa foi uma professora do Colégio de Aplicação da UFPE, que regia, na época, uma turma do $6^{\circ}$ ano. Ela desenvolveu uma sequência didática envolvendo o gênero notícia e contendo atividades de produção, avaliação, revisão e reescrita. Utilizamos, como procedimento de geração de dados, a autoconfrontação simples, tal como concebida por Clot $(2007,2010)$, tendo sido a professora convidada, em cinco encontros, a assistir a suas aulas (gravadas em vídeo) e a falar sobre elas. Para analisarmos os dados, nos baseamos no conceito de "esquemas profissionais", delimitado por Goigoux (2001, 2002, 2007) e Goigoux e Vergnaud (2005). Através das análises, verificamos que a professora explicitou verbalmente os esquemas mobilizados durante a sequência didática para ensinar seus alunos a produzirem textos. Assim, ela conseguiu esclarecer, sem dificuldade e com propriedade, quais eram os seus objetivos didáticos, bem como as regras de ação e os teoremas em ação por ela mobilizados em sala de aula. Notamos também uma articulação estreita entre sua prática e os pressupostos teóricometodológicos que constituem a perspectiva de ensino sociointeracionista. Por fim, a pesquisa indicou que pode haver ganhos na utilização de procedimentos como a autoconfrontação nas pesquisas que tratem dos fazeres docentes.

Palavras-chave: Ensino de produção de texto; Autoconfrontação; Esquemas profissionais. 
Abstract: In this research, we investigated teacher's reflection about her teaching of textual production. The subject was a professor at the College of Application at UFPECAp, who ruled, at the time, a 6th grade class. She developed a didactic sequence involving the news genre, containing activities of production, evaluation, review and rewriting. As data generation procedure, we used simple self-confrontation, as defined by Clot $(2007 ; 2010)$, in which the teacher was invited to watch five of her video-recorded classes and to talk about them. Data analysis were based on the concept of "professional schemes", delimited by Goigoux (2001; 2002; 2007) and Goigoux and Vergnaud (2005). According to the data analysis, we verified that the teacher verbally explained the schemes used during the didactic sequence to teach her students how to produce texts. Thus, she was able to properly and without difficulty clarify her didactic objectives, as well as the rules of action and the theorems in action mobilized in the classroom. We noticed a close articulation between her practice and the theoretical-methodological assumptions that constitute the perspective of sociointeractionist teaching. Finally, the research indicated that there may be gains in the use of procedures such as self-confrontation in research that deals with teaching activities.

Keywords: Teaching text production; Self-confrontation; Professional schemes.

\section{Introdução}

O ensino da produção de texto tem sido objeto de muitas pesquisas recentes nos campos da Educação e da Linguística Aplicada. Uma breve análise de tais estudos nos permite identificar que grande parte deles tem como finalidade descrever e analisar o ensino realizado por professores experientes, identificando formas rotineiras de organização da sua atividade docente e comparando-as com as de outros professores. Goigoux (2001) caracteriza tais pesquisas como de natureza extrínseca, uma vez que o ensino dos professores é observado e analisado apenas pelo pesquisador, um agente externo. Entretanto, esse autor alerta para as limitações das investigações de natureza apenas extrínseca, na medida em que não tomam o professor como sujeito e acabam, muitas vezes, negligenciando esses indivíduos, os quais permitem ser observados sem, todavia, poderem agir sobre sua prática. 
Um modo de devolver a palavra ao professor nas pesquisas seria por meio da metodologia denominada "autoconfrontação" gias da Clínica do Trabalho, desenvolvida por Clot (2007, 2010), a autoconfrontação aplicada ao contexto de ensino é realizada através de sessões de observação, por parte do professor, de suas aulas gravadas em vídeo. Nessas ocasiões, ele é levado a pensar e a falar sobre seus objetivos, suas escolhas, sua mediação etc.

Ao questionarmos sobre o uso de tal metodologia, nos perguntamos: Se fosse dada aos professores a oportunidade de refletir sobre seu ensino da produção textual, que aspectos de sua prática conheceríamos? Nesse sentido, investigamos, nesta pesquisa, o processo de reflexão por parte de uma professora de Língua Portuguesa sobre o seu ensino da produção textual em uma turma do $6^{\circ}$ ano do ensino fundamental. Tivemos como intenção descrever e analisar o ensino de uma professora experiente, identificando formas rotineiras de organização da sua atividade docente e estudando o seu trabalho tal como a própria professora o concebe e o compreende.

\section{O ensino da produção de texto numa perspectiva sociointeracionista}

Tomando como base uma visão de língua como interação e acreditando que o ensino da Língua Portuguesa tem como objetivo principal capacitar os indivíduos para atuar nas mais diversas situações comunicativas, ou seja, formar usuários proficientes, que saibam utilizar a língua como instrumento para refletir e agir (OLIVEIRA, 2000), defendemos uma perspectiva de ensino da produção de texto a partir dos gêneros textuais. Assim como Costa Val e Vieira (2005, p. 41), entendemos que:

um projeto de ensino que vise à apropriação e ao desenvolvimento das habilidades de interação pela escrita, num determinado contexto social e cultural, deve, necessariamente, criar oportunidades adequadas para que os alunos descubram a escrita como forma de interação social, como atividade discursiva.

Como discute Motta-Roth (2006), se considerarmos que a língua é um fenômeno social, então devemos admitir que a sua aquisição é, também, um processo voltado para as interações sociais. Isso porque a criança tem contato com a língua materna através dos textos lidos e produzidos ao seu redor e, a partir deles, constrói representações sobre como ela funciona. Assim, podemos dizer que a criança aprende a língua porque participa da vida social. Da mesma forma, à medida que cresce, também podemos afirmar o

\footnotetext{
${ }^{1}$ O termo "autoconfrontação" diz respeito a um procedimento de coleta de dados através do qual o professor é confrontado com sua própria prática ao assistir a suas aulas em vídeo e ser motivado a falar sobre elas.
} 
contrário: a criança participa melhor da vida social porque sabe cada vez mais sobre a língua. A autora usa esse mesmo raciocínio para o ensino e afirma que o aluno precisa agir em diversas situações de interação social para aprender mais sobre os usos da língua. Isso porque o aluno sabe português, mas não sabe agir linguisticamente em determinadas situações. É através da participação do aluno em atividades socialmente partilhadas que ele irá desenvolver as habilidades linguísticas necessárias ao uso da língua escrita. Nesse sentido, Motta-Roth (2006) reafirma o papel da escola no sentido de proporcionar aos alunos contextos ou situações nos quais eles possam colocar em prática competências e conhecimentos linguísticos para realizar determinadas atividades sociais.

Bunzen (2006) salienta que a opção do professor por uma prática de ensino da produção de texto distanciada das ou pautada nas práticas sociais não é neutra:

\begin{abstract}
É decisão política escolher se teremos como objetivo principal e final a formação de alunos no EM que produzem na escola (e nos cursinhos) apenas as propostas de redações do vestibular das principais universidades de cada estado ou investiremos em um processo de ensino-aprendizagem que leve em consideração a prática social de produção de textos em outras esferas de comunicação. (BUNZEN, 2006, p. 151).
\end{abstract}

Tal perspectiva vem sendo construída desde o final dos anos 1970 e início dos anos 1980. Assim, passou-se a ter uma preocupação maior com os contextos de produção e de circulação dos textos - quem está falando, com quem, com que objetivos, de forma etc. (BUNZEN, 2006). Nesta seção, vamos apontar algumas diretrizes para o ensino da produção de texto nessa direção.

Uma primeira diretriz é que o professor precisa promover situações de escrita parecidas com as que vivenciamos em contextos extraescolares. Isso quer dizer que os alunos precisam experimentar os diversos usos sociais da escrita, produzindo textos para atender a objetivos e interlocutores concretos. Sobre essa diretriz, Motta-Roth (2006) salienta que ela não significa, apenas, achar um lugar para a escrita na vida do aluno, mas também ampliar o leque de possibilidades de experiências vivenciadas por ele, "trazendo o mundo para a sala de aula e levando o aluno a vivenciar o mundo 'lá fora”" (MOTTA-ROTH, 2006, p. 503).

Além disso, escrever um texto se torna uma tarefa difícil e vazia quando sua única motivação é cumprir uma tarefa escolar e seu único interlocutor é o professor. Como comentam Menegassi e Fuza (2008), quando o estudante visualiza somente o professor e os colegas como interlocutores, a finalidade da escrita fica restrita a atender ao que foi solicitado na atividade e demonstrar sua competência de escrita para eles. Com isso, 
o estudante não tem a oportunidade de considerar destinatários "superiores" (além dos muros da escola) e de escrever para o meio social. Para que a aprendizagem seja significativa, relevante e eficaz, é necessário realizar atividades autênticas de escrita, nas quais os textos dos alunos tenham verdadeiras funções sociais e os leitores sejam concretos, de modo a serem levados em conta durante a escrita e influenciarem as decisões tomadas pelo aluno-escritor no que diz respeito ao que dizer e ao como dizer.

Outra diretriz apontada é que essas situações de escrita precisam ser diversificadas, ou seja, devem representar diferentes esferas de interação social, variando-se os interlocutores e as finalidades almejadas. Isso porque cada situação de interação demanda do escritor a mobilização de habilidades e saberes diferentes, os quais não são aprendidos espontaneamente, e precisam, sim, ser ensinados, conforme explicam Leal e Melo (2006). Costa Val e Vieira (2005, p. 8) também reforçam essa ideia ao explicitar que é papel do professor "contribuir para o desenvolvimento de habilidades e competências de uso da escrita em diferentes situações de comunicação”.

A terceira diretriz é que os alunos sejam levados a produzir textos de diferentes gêneros textuais. Isso se justifica pelo fato de que todo texto se materializa em algum gênero textual. A esse respeito, Bronckart (1991 apud OLIVEIRA, 2000) propõe que o ensino da língua materna (principalmente o da produção de texto) seja colocado em prática através do que ele denomina de didática da diversificação, a qual se caracteriza pela introdução dos variados gêneros textuais nas aulas, partindo do pressuposto de que o seu domínio é essencial para a vida social e profissional dos sujeitos. Adam (1991 apud OLIVEIRA, 2000), em concordância com essa proposição de Bronckart, também salienta que aprender a escrever é aprender a estruturar enunciados em gêneros do discurso. Ao dominar os gêneros que organizam um determinado grupo social e uma determinada cultura, o aluno aprende formas de participar das ações de uma comunidade específica (MOTTA-ROTH, 2006). Bunzen (2006, p. 149) também apoia essa perspectiva, ao defender que:

Os alunos não deveriam produzir "redações", meros produtos escolares, mas textos diversos que se aproximassem dos usos extraescolares, com função específica e situada dentro de uma prática social escolar. Se assumirmos tal posicionamento, apostaremos em um ensino muito mais procedimental e reflexivo (e menos transmissivo), que leva em consideração o próprio processo de produção de textos e que vê a sala de aula, assim como as esferas da comunicação humana, como um lugar de interação verbal.

É importante, ainda, ficarmos atentos à frequência com que propomos situações de 
produção de textos na escola, pois a recorrência de práticas também é importante para o desenvolvimento das habilidades necessárias à escrita, embora apenas isso não garanta o aprendizado.

Por fim, uma última diretriz salienta que a produção textual deve ser vivenciada na escola como um processo composto por diferentes etapas, como explicam Santos e Teixeira (2016, p. 40):

\begin{abstract}
A produção textual precisa ser entendida como um processo (atividade processual): começa na discussão ou estudo do tema; no entendimento da tipologia predominante e do gênero solicitado; passa pelo roteiro, esboço, redação e revisão; envolve o destinatário que o avaliará (outro colega, professor etc.) e, depois, retorna ao produtor para o texto ser reescrito se necessário. Finalmente, este precisa circular, chegar a outros destinatários.
\end{abstract}

Diante das diretrizes apontadas, reafirmamos nossa crença nessa perspectiva de ensino de produção de texto, segundo a qual se defende a promoção de situações parecidas com as que vivenciamos fora da escola, sendo estas reais e referentes às diferentes esferas de interação social. Como bem sintetizou Oliveira (2000), nessa perspectiva, produzir textos escritos é uma atividade de transformar um objeto interno (ideias, conteúdos, sentimentos, opiniões, informações etc.) em um objeto externo (o texto), com o intuito de resolver problemas comunicativos e interagir com um interlocutor real e distante. Por sua vez, isso implica tomar o texto escrito como unidade de ensino e, principalmente, como mediador do processo de interlocução.

\title{
2. Atividade de pensamento do professor em situação de trabalho: o papel dos esquemas profissionais
}

Recorremos aos estudos de Goigoux (2001, 2002, 2007) e Goigoux e Vergnaud (2005) para tentar compreender a atividade de pensamento do professor em situação de trabalho. Essa análise das ações docentes permite-nos observar e identificar condutas realizadas pelo professor que se repetem de modo regular no cotidiano de sala de aula e que, por isso, parecem fazer parte da organização do seu modo de ensinar. Tais condutas, com base na teoria de Vergnaud (1996), podem ser entendidas como seus esquemas profissionais. Podemos conceituar, então, os esquemas profissionais como formas invariáveis e estabilizadas de atividade de ensino de um professor que se destacam dentro de certa variedade de situações pertencentes a uma mesma classe (GOIGOUX, 2002, 2007; GOIGOUX; VERGNAUD, 2005).

Goigoux e Vergnaud (2005) salientam, todavia, que os esquemas não são propria- 
mente as condutas docentes, mas suas representações, sendo sua principal função gerar as atividades do professor durante as interações com seus alunos e no desenvolvimento de sequências didáticas. Mais especificamente, os esquemas permitem ao professor promover ajustes adequados às crianças quanto à aprendizagem de determinado aspecto, como veremos mais adiante. Da mesma forma, na análise dos esquemas, interessam todos os registros de atividade do professor, desde gestos e linguagens usadas, até julgamentos e raciocínios (GOIGOUX; VERGNAUD, 2005).

Por sua vez, um esquema é formado por quatro elementos ou dimensões - objetivos, regras de ação, invariantes operatórios e inferências (GOIGOUX; VERGNAUD, 2005; GOIGOUX, 2007) -, os quais aparecem integrados e construindo uma unidade:

1 - Objetivo ou meta: de acordo com o planejamento da atividade de ensino, o professor tem certas metas e objetivos que busca alcançar para que sua ação tenha sucesso e seus alunos consigam aprender. Assim, por exemplo, o professor pode ter como meta permitir a cada aluno encontrar uma resposta para um determinado problema proposto e, ao mesmo tempo, ajudar todos a aprenderem os procedimentos que foram utilizados para dar conta da referida tarefa.

2 - Regras de ação: a partir da atividade do professor, desenvolvida ao longo de uma sequência didática, podemos depreender certas ações que são frequentes em sua prática, mesmo que elas não sejam totalmente explicitadas por ou conscientes para ele. Por sua vez, essas regras se subdividem em três: regras de captura de informações, que consistem na tomada de informações sobre o modo de pensar e agir do aluno (Como ele encara o problema proposto? O que ele está tentando fazer? Como ele procede?); regras de ação, que dizem respeito aos tipos de procedimentos efetivamente realizados pelo professor (ex.: a divisão da tarefa em subtarefas, a demonstração dos procedimentos para os alunos, a representação gráfica dos procedimentos no quadro, a condução de um diálogo com aluno, a realização de certos gestos, a alternância entre a atividade do professor e a do aluno etc.); e regras de controle, que dizem respeito a uma certificação por parte do professor sobre se os procedimentos adotados foram suficientes para gerar aprendizado (ex.: Eu orientei bem os procedimentos? Agora, os alunos conseguirão fazer sozinhos? Todos os alunos conseguiram aprender?).

3 - Os conceitos em ato e os teoremas em ato (ou em ação): são princípios que estruturam, organizam e viabilizam as ações docentes. Parte-se da ideia de que as escolhas didáticas realizadas pelo professor se baseiam em proposições que eles jul- 
gam como verdadeiras. Por exemplo, diante da dificuldade externada por um aluno em particular, o professor escolhe refletir sobre essa dificuldade com todos da turma. Essa decisão decorre de um determinado teorema em ação que o professor tem e que pode ser assim definido: a demonstração coletiva dos procedimentos usados para resolver certo problema pode beneficiar não só o aluno com dificuldade, mas todos os outros. Pelo fato de essas conceituações acontecerem durante a ação do professor (e não serem, necessariamente, explicitadas por ele), elas podem ser chamadas de invariantes operatórias ou operacionais. Vale destacar que a elaboração dessas invariantes advém de reflexões e ações de docentes experientes que já testaram mais formas de ação e optaram por elas para obterem bons resultados de aprendizagem dos seus alunos.

4 - As inferências ${ }^{2}$ : tomando como base aquilo em que o professor acredita (invariantes operatórias), as inferências lhe permitem calcular em pensamento o que pretende fazer e o que efetivamente fará (objetivos e regras).

Por fim, é importante reiterarmos que o conceito de esquemas será importante neste trabalho, uma vez que funcionará como ferramenta de análise da prática da professora em sala de aula. Como vimos, os esquemas são usados intencionalmente pelos professores, mas isso não significa que sejam sempre explícitos para eles. Nesse sentido, as entrevistas de autoconfrontação que realizamos acabaram forjando uma consciência de sua prática por parte da professora-colaboradora, e é nossa intenção resgatar os esquemas explicitados por ela nesses momentos.

\section{Procedimentos metodológicos}

A nossa investigação pode ser caracterizada como de natureza colaborativa (PIMENTA, 2005). Isso porque a professora foi colaboradora da pesquisa, na medida em que também participou de uma parte da análise dos dados ao ser provocada a, sob a mediação de uma das pesquisadoras, problematizar sua atuação durante as atividades de produção textual. Nesse processo, consideramos a docente como sujeito ativo, capaz de contribuir com a nossa pesquisa através da elaboração de conhecimentos sobre o seu ensinar, obtidos por meio da reflexão crítica.

A professora-colaboradora da pesquisa - aqui chamada de Clarice ${ }^{3}$ - é uma docente de

\footnotetext{
${ }^{2}$ A realização de inferências pela professora, isto é, o cálculo, em pensamento, do que ela pretende fazer (objetivo) e do que vai fazer (regra de ação), tomando como referência aquilo em que acredita (teorema em ação), mostrou-se uma ação inexpressiva nos encontros de autoconfrontação e irrelevante para alcançarmos os objetivos pretendidos com esta pesquisa. Por esse motivo, não trabalhamos com tal categoria.

${ }^{3}$ Nome fictício escolhido pela pesquisadora, a pedido da professora.
} 
Língua Portuguesa do Colégio de Aplicação da Universidade Federal de Pernambuco (CApUFPE), a qual é licenciada em Letras, tem mestrado e doutorado em Linguística, e contabiliza 20 anos de experiência em sala de aula.

A pesquisa foi realizada através de dois instrumentos: observação e autoconfrontação. No que diz respeito às observações, acompanhamos uma sequência didática sobre o gênero textual notícia desenvolvida pela professora Clarice em uma turma de $6^{\circ}$ ano do ensino fundamental, contendo atividades de produção, avaliação, revisão e reescrita textuais. A sequência didática da professora Clarice teve início no dia 09 de outubro de 2017 e terminou em 07 de dezembro do mesmo ano, estendendo-se durante 18 dias de atividades e totalizando 33 horas-aula, as quais foram gravadas em áudio e filmadas em vídeo.

Por fim, em se tratando da autoconfrontação, a professora foi convidada, em cinco encontros, a assistir a suas aulas e a falar sobre elas. Nesses encontros de autoconfrontação, a docente assistiu trechos dos vídeos contendo as atividades de produção de texto realizadas com seus alunos, ao mesmo tempo em que foi levada, através de questões problematizadoras levantadas pela pesquisadora, a comentar sobre sua prática, refletindo sobre aspectos como os objetivos que tinha ao realizar as atividades, os aspectos trabalhados e sua mediação.

Nosso objetivo ao realizar esses encontros foi dar à professora a oportunidade de refletir sobre seu trabalho docente e, consequentemente, articular o pensar e o agir durante a pesquisa. Realizamos praticamente um encontro por semana, sendo cada um referente a dois ou três dias de aulas. Os encontros duraram, em média, uma hora e foram realizados sempre ao final das aulas. Para analisarmos os dados gerados, baseamo-nos no conceito de esquemas delimitado por Goigoux (2001; 2002; 2007) e Goigoux e Vergnaud (2005), os quais já foram discutidos em seção anterior.

\section{Resultados e discussão}

As verbalizações de Clarice, durante os encontros de autoconfrontação, ajudaram-nos a compreender melhor alguns procedimentos utilizados por uma professora experiente para ensinar seus alunos a produzirem textos. Assim, pudemos identificar 14 esquemas relacionados à elaboração de textos. De uma forma geral, observamos que ao conjunto de tais esquemas subjazem uma concepção interacionista de língua (VOLOSHINOV, 2002) e o reconhecimento da natureza social da atividade de produção de textos, na medida em que Clarice faz da sala de aula e da escola lugares autênticos de interação, nos quais ela, seus alunos e os demais membros da comunidade escolar dialogam e interagem entre si.

Da mesma forma, através desses esquemas, nota-se que a professora compreende a produção de texto como um processo complexo, o qual implica diferentes procedimentos interdependentes e intercomplementares, tais como: planejar, gerar-selecionar-organizar as ideias, elaborar um esboço do texto, textualizar, avaliar, revisar, reescrever, construir uma versão final e socializar com a audiência-alvo; por isso, o desenvolvimento da habilidade de produzir textos por parte dos seus alunos demanda um longo e trabalhoso processo de escrita e reescrita de textos. 
Além disso, por meio de tais esquemas, constatamos que, para a docente, é nas práticas interativas de escrita promovidas pela escola que os alunos devem aprender como usar a língua em diferentes situações discursivas e, por isso, ela tenta estabelecer a prática social como ponto de partida das aulas de produção de texto. Para tanto, conforme também indicam os esquemas em questão, Clarice assume uma perspectiva de ensino da produção de texto a partir dos gêneros textuais, levando seus alunos a compreendê-los em meio às suas práticas de uso e a escrever textos à moda de gêneros diversos (DOLZ; SCHNEUWLY, 2004).

Por sua vez, tais esquemas foram mobilizados pela professora em diferentes momentos da produção textual. Assim, identificamos pelo menos quatro esquemas voltados para os momentos anteriores à escrita propriamente dita:

Quadro 1. Esquemas relacionados ao ensino da produção textual voltados para o momento anterior à escrita

\begin{tabular}{|c|c|c|c|}
\hline Esquema & Objetivo didático & Regra de ação & Teorema em ação \\
\hline $\begin{array}{l}\text { Propor temas cotidia- } \\
\text { nos para as produções } \\
\text { de textos }\end{array}$ & $\begin{array}{l}\text { Para que os alunos se } \\
\text { familiarizassem com } \\
\text { esse tema e se engajas- } \\
\text { sem na proposta. }\end{array}$ & $\begin{array}{l}\text { Propõe uma produção } \\
\text { a partir de um tema que } \\
\text { retrata o cotidiano dos } \\
\text { alunos na escola. }\end{array}$ & $\begin{array}{l}\text { Porque, às vezes, você } \\
\text { propõe um trabalho para } \\
\text { ser feito no coletivo e os } \\
\text { alunos não gostam, não } \\
\text { querem fazer. Então, eu já } \\
\text { procurei um tema que, de } \\
\text { algum modo, retratasse um } \\
\text { pouco do cotidiano deles } \\
\text { pra que eles se familiarizas- } \\
\text { sem com esse tema e aí se } \\
\text { engajassem na proposta. }\end{array}$ \\
\hline $\begin{array}{l}\text { Apresentar e discutir } \\
\text { as condições de pro- } \\
\text { dução do texto }\end{array}$ & $\begin{array}{l}\text { Saber que todo gênero } \\
\text { textual está correlacio- } \\
\text { nado com a situação de } \\
\text { funcionamento social. }\end{array}$ & $\begin{array}{l}\text { Explicita a situação de } \\
\text { comunicação do texto } \\
\text { (O quê? Para quem? } \\
\text { Para quê? Participação } \\
\text { na produção? Onde será } \\
\text { publicada? Quando?) e } \\
\text { discute as implicações } \\
\text { dessas condições de } \\
\text { produção para a escrita } \\
\text { do texto (na produção } \\
\text { inicial e na produção fi- } \\
\text { nal). }\end{array}$ & $\begin{array}{l}\text { As minhas escolhas para a } \\
\text { escrita dependem de eu en- } \\
\text { tender como funciona esse } \\
\text { contexto. Então, eu tenho } \\
\text { que entender esse contexto } \\
\text { para poder adequar minha } \\
\text { linguagem da melhor for- } \\
\text { ma possível. }\end{array}$ \\
\hline
\end{tabular}




\begin{tabular}{|c|c|c|c|}
\hline $\begin{array}{l}\text { Fornecer algumas in- } \\
\text { formações sobre o gê- } \\
\text { nero textual antes de } \\
\text { realizar a produção } \\
\text { inicial }\end{array}$ & $\begin{array}{l}\text { Para que seja possível } \\
\text { depois avaliar o texto } \\
\text { com base nas minhas } \\
\text { expectativas sobre o } \\
\text { gênero textual. }\end{array}$ & $\begin{array}{l}\text { Retoma as característi- } \\
\text { cas do gênero textual (já } \\
\text { discutidas) usando um } \\
\text { texto do mesmo gênero } \\
\text { lido e debatido em aula } \\
\text { anterior. } \\
\text { Lê um novo exemplar } \\
\text { do gênero textual e dis- } \\
\text { cute coletivamente suas } \\
\text { características. }\end{array}$ & $\begin{array}{l}\text { Se eu não digo o que eu } \\
\text { espero minimamente para } \\
\text { o gênero textual, o aluno } \\
\text { pode fazer de qualquer jei- } \\
\text { to e, fazendo de qualquer } \\
\text { jeito, eu não vou ter um } \\
\text { parâmetro para ver o que } \\
\text { ele está compreendendo. }\end{array}$ \\
\hline $\begin{array}{l}\text { Planejar coletivamen- } \\
\text { te a produção de texto }\end{array}$ & $\begin{array}{l}\text { Mostrar que as coisas } \\
\text { não funcionam indivi- } \\
\text { dualmente. } \\
\text { Para que os alunos } \\
\text { pudessem se organi- } \\
\text { zar em grupo em duas } \\
\text { sistemáticas: cada um } \\
\text { ver o que já fez e o que } \\
\text { deixou de fazer, bem } \\
\text { como socializar com } \\
\text { seus colegas o que está } \\
\text { pensando para o seu } \\
\text { texto e obter deles con- } \\
\text { tribuições. }\end{array}$ & $\begin{array}{l}\text { Reúne os alunos em pe- } \\
\text { quenos grupos e pede } \\
\text { para eles planejarem } \\
\text { coletivamente a escrita } \\
\text { dos seus textos. Nessas } \\
\text { reuniões, os alunos são } \\
\text { orientados a realizar: } \\
\text { proposição e definição } \\
\text { dos temas de cada tex- } \\
\text { to; exposição dos temas } \\
\text { pensados por cada um } \\
\text { para o seu texto; apre- } \\
\text { ciação, pelo grupo, dos } \\
\text { temas propostos; plane- } \\
\text { jamento das próximas } \\
\text { atividades que serão ne- } \\
\text { cessárias para elaborar } \\
\text { os textos (ex.: realizar } \\
\text { pesquisas, fazer entre- } \\
\text { vistas, conseguir uma } \\
\text { imagem etc.); registro } \\
\text { das decisões do grupo } \\
\text { nos cadernos e em uma } \\
\text { folha. Para dar suporte e } \\
\text { guiar os alunos na reali- } \\
\text { zação dessa atividade, a } \\
\text { professora entrega uma } \\
\text { ficha (a ser preenchida e } \\
\text { devolvida no final) com } \\
\text { os aspectos que devem } \\
\text { ser observados durante } \\
\text { o planejamento, explica } \\
\text { como realizá-lo e circu- } \\
\text { la pela sala ajudando os } \\
\text { grupos. }\end{array}$ & $\begin{array}{l}\text { A própria produção da no- } \\
\text { tícia está articulada com } \\
\text { um coletivo, a um caderno, } \\
\text { que é menor; a um jornal, } \\
\text { que é maior; a uma comu- } \\
\text { nidade, que é maior ainda; } \\
\text { então, as coisas estão todas } \\
\text { integradas. } \\
\text { Se eu presumo que os alu- } \\
\text { nos não trouxeram o mate- } \\
\text { rial necessário para realizar } \\
\text { a produção de texto, eles } \\
\text { também não vão deixar } \\
\text { de fazer. Então, já que os } \\
\text { alunos não estão prepara- } \\
\text { dos para escrever naquela } \\
\text { aula, esse é o momento de } \\
\text { se organizar e se planejar, } \\
\text { definindo o que vão querer } \\
\text { e o que vão precisar, por- } \\
\text { que vai ser até mais rápido } \\
\text { conseguir o que falta mais } \\
\text { adiante e porque o prazo } \\
\text { de entrega do texto está } \\
\text { próximo e eles precisam } \\
\text { dar conta da atividade. } \\
\text { Pensar sobre o seu trabalho } \\
\text { em grupo é também pensar } \\
\text { sobre como se organizar na } \\
\text { escola, como se organizar } \\
\text { nos trabalhos, não só de } \\
\text { português, mas de mate- } \\
\text { mática, geografia etc. }\end{array}$ \\
\hline
\end{tabular}

Fonte: As autoras. 
Como podemos perceber, esses esquemas foram usados pela professora para propor a produção de texto e preparar os alunos para a escrita. Ao analisarmos os esquemas mobilizados por Clarice, antes da produção, notamos, inicialmente, uma tendência da professora de escolher práticas de escrita significativas para seus alunos, o que, provavelmente, exigiu dela estar atenta aos temas, textos e usos que fazem parte do cotidiano da turma para, a partir desse diagnóstico, planejar os processos de ensino e de aprendizagem da escrita.

Igualmente, os esquemas anteriormente apresentados apontam para a ideia de que a produção de texto é uma ação ocorrida em um dado contexto, cujos fatores vão influenciar todo o processo de produção. Nesse sentido, aprender a escrever envolve aprender a construir representações adequadas desse contexto de produção e circulação. Para tanto, caberia à professora levar seus alunos a refletirem sobre os elementos que dele fazem parte e compreenderem suas implicações para a escrita do texto.

Tais esquemas indicam, ainda, a preocupação da professora com um ensino sistemático da língua escrita, através do qual ela promove uma reflexão sobre os textos lidos e produzidos em sala de aula de modo a ajudar seus alunos a se apropriarem das características dos diversos gêneros textuais e, assim, serem capazes de produzi-los (DOLZ; SCHNEUWLY, 2004).

Da mesma forma, identificamos seis esquemas voltados para o decorrer da escrita:

Quadro 2. Esquemas relacionados ao ensino da produção textual voltados para o decorrer da escrita

\begin{tabular}{|c|c|c|c|}
\hline Esquema & Objetivo didático & Regra de ação & Teorema em ação \\
\hline $\begin{array}{l}\text { Realizar uma pro- } \\
\text { dução de texto no } \\
\text { início da sequên- } \\
\text { cia didática }\end{array}$ & $\begin{array}{l}\text { Saber, mais ou me- } \\
\text { nos, o que os alu- } \\
\text { nos já tinham de } \\
\text { informação da es- } \\
\text { trutura e da organi- } \\
\text { zação das notícias } \\
\text { para poder, assim, } \\
\text { selecionar os as- } \\
\text { pectos que ainda } \\
\text { não dominavam } \\
\text { sobre o gênero, mas } \\
\text { que precisavam } \\
\text { aprender ao longo } \\
\text { da sequência. }\end{array}$ & $\begin{array}{l}\text { Realiza uma pro- } \\
\text { dução de texto no } \\
\text { início, tomando } \\
\text { como base o mes- } \\
\text { mo gênero textual } \\
\text { que será enfocado } \\
\text { durante a sequên- } \\
\text { cia didática. }\end{array}$ & $\begin{array}{l}\text { Como a gente ainda não } \\
\text { tinha trabalhado ne- } \\
\text { nhum conteúdo em re- } \\
\text { lação ao gênero notícia, } \\
\text { era possível saber o que } \\
\text { os alunos já traziam de } \\
\text { informação prévia sobre } \\
\text { ele. }\end{array}$ \\
\hline
\end{tabular}




\begin{tabular}{|c|c|c|c|}
\hline $\begin{array}{l}\text { Realizar uma pro- } \\
\text { dução de texto ao } \\
\text { final da sequência } \\
\text { didática }\end{array}$ & Não identificado. & $\begin{array}{l}\text { Realiza uma nova } \\
\text { produção de texto } \\
\text { ao final, tomando } \\
\text { como base o mes- } \\
\text { mo gênero textual } \\
\text { que foi enfocado } \\
\text { durante a sequên- } \\
\text { cia didática. }\end{array}$ & $\begin{array}{l}\text { E aí eu faço também as } \\
\text { minhas anotações, te- } \\
\text { nho minha tabelinha e } \\
\text { aí, cada item, eu vou bo- } \\
\text { tando "mais", "mais ou } \\
\text { menos", "menos", para } \\
\text { que depois eu saiba, } \\
\text { quando eu pegar o últi- } \\
\text { mo texto deles, em que } \\
\text { foi que eles avançaram, } \\
\text { comparando com essa } \\
\text { produção inicial. }\end{array}$ \\
\hline $\begin{array}{l}\text { Realizar interven- } \\
\text { ções orais e coleti- } \\
\text { vas durante a pro- } \\
\text { dução de texto }\end{array}$ & $\begin{array}{l}\text { Para que os alunos } \\
\text { não continuassem } \\
\text { errando. }\end{array}$ & $\begin{array}{l}\text { Durante a escrita } \\
\text { de texto individu- } \\
\text { al, interrompe a } \\
\text { produção em al- } \\
\text { guns momentos } \\
\text { para realizar in- } \\
\text { tervenções orais e } \\
\text { coletivas, fazendo } \\
\text { observações so- } \\
\text { bre dificuldades } \\
\text { percebidas por ela } \\
\text { durante o processo } \\
\text { de escrita. }\end{array}$ & $\begin{array}{l}\text { Se várias pessoas es- } \\
\text { tão me perguntando a } \\
\text { mesma coisa ou eu vi } \\
\text { um erro se repetindo } \\
\text { em mais de um texto } \\
\text { quando eu passei entre } \\
\text { as bancas, eu prefiro e } \\
\text { acho necessário, em vez } \\
\text { de ficar falando com um } \\
\text { e com outro, fazer uma } \\
\text { intervenção coletiva. }\end{array}$ \\
\hline $\begin{array}{l}\text { Recolher os rascu- } \\
\text { nhos dos textos }\end{array}$ & $\begin{array}{l}\text { Evitar que os alu- } \\
\text { nos esqueçam os } \\
\text { rascunhos dos tex- } \\
\text { tos em casa. }\end{array}$ & $\begin{array}{l}\text { Recolhe os rascu- } \\
\text { nhos dos textos } \\
\text { produzidos até o } \\
\text { momento para os } \\
\text { alunos continua- } \\
\text { rem a escrita em } \\
\text { outra aula (não } \\
\text { deixando os alu- } \\
\text { nos levarem o tex- } \\
\text { to para casa). }\end{array}$ & $\begin{array}{l}\text { Se você atribui à turma } \\
\text { a responsabilidade de } \\
\text { levar um material para a } \\
\text { sala de aula, mas ela não } \\
\text { leva, isso vai prejudicar } \\
\text { o que você tinha plane- } \\
\text { jado e você vai ter que } \\
\text { pensar num plano B. } \\
\text { Para se antecipar a isso: } \\
\text { "Posso levar pra casa pra } \\
\text { terminar?" Não. Vou tra- } \\
\text { zer de volta, porque eu } \\
\text { tenho um propósito e eu } \\
\text { sei que, se alguém deixar } \\
\text { de trazer, isso vai inter- } \\
\text { ferir. }\end{array}$ \\
\hline
\end{tabular}




\begin{tabular}{|c|c|c|c|}
\hline $\begin{array}{l}\text { Devolver os rascu- } \\
\text { nhos dos textos }\end{array}$ & $\begin{array}{l}\text { Evitar que os alu- } \\
\text { nos esqueçam os } \\
\text { rascunhos dos tex- } \\
\text { tos em casa. }\end{array}$ & $\begin{array}{l}\text { Devolve os rascu- } \\
\text { nhos dos textos } \\
\text { produzidos até o } \\
\text { momento para os } \\
\text { alunos continua- } \\
\text { rem a escrita em } \\
\text { sala de aula. }\end{array}$ & $\begin{array}{l}\text { Se você atribui à turma } \\
\text { a responsabilidade de } \\
\text { levar um material para a } \\
\text { sala de aula, mas ela não } \\
\text { leva, isso vai prejudicar } \\
\text { o que você tinha plane- } \\
\text { jado e você vai ter que } \\
\text { pensar num plano B. } \\
\text { Para se antecipar a isso: } \\
\text { "Posso levar pra casa pra } \\
\text { terminar?" Não. Vou tra- } \\
\text { zer de volta, porque eu } \\
\text { tenho um propósito e eu } \\
\text { sei que, se alguém deixar } \\
\text { de trazer, isso vai inter- } \\
\text { ferir. }\end{array}$ \\
\hline $\begin{array}{l}\text { Receber os alunos } \\
\text { no birô para tirar } \\
\text { dúvidas sobre a } \\
\text { produção de texto }\end{array}$ & $\begin{array}{l}\text { Não atrapalhar o } \\
\text { andamento do tra- } \\
\text { balho. } \\
\text { Fazer com que os } \\
\text { alunos pudessem } \\
\text { concentrar-se indi- } \\
\text { vidualmente e fazer } \\
\text { o seu registro. }\end{array}$ & $\begin{array}{l}\text { Permanece sen- } \\
\text { tada em seu birô } \\
\text { durante toda a aula } \\
\text { recebendo os alu- } \\
\text { nos que tenham } \\
\text { dúvidas (ao invés } \\
\text { de ficar circulando } \\
\text { pela sala). }\end{array}$ & $\begin{array}{l}\text { Durante a produção de } \\
\text { texto individual, só aju- } \\
\text { do os alunos em relação } \\
\text { a questões pontuais. } \\
\text { O aluno mesmo tem } \\
\text { que escrever, o texto é } \\
\text { dele, tem que ter a sua } \\
\text { autoria e autonomia. } \\
\text { Mais à frente vai ter um } \\
\text { momento em que eu e } \\
\text { outras pessoas vamos } \\
\text { ler seu texto e ajudar a } \\
\text { melhorá-lo, mas esse } \\
\text { momento é o momento } \\
\text { para ele escrever e não } \\
\text { para eu dizer o que tem } \\
\text { que escrever. Às vezes, } \\
\text { você dá uma ajuda, mas } \\
\text { você não pode, o tem- } \\
\text { po todo, estar dizendo o } \\
\text { que eles têm que dizer. } \\
\text { Se não fizer dessa forma, } \\
\text { eles me procurarão o } \\
\text { tempo todo para validar } \\
\text { sua escrita e isso atrasará } \\
\text { o andamento da produ- } \\
\text { ção. Agora é o momento } \\
\text { de colocar em prática } \\
\text { aquilo que a gente havia } \\
\text { aos poucos trabalhado } \\
\text { em sala de aula. }\end{array}$ \\
\hline
\end{tabular}

Fonte: As autoras. 
Esses esquemas foram mobilizados pela professora para gerenciar o momento de escrita em sala de aula e ajudar os alunos a efetivamente realizarem a atividade. Eles apontam, primeiramente, para a adesão da professora Clarice ao procedimento denominado sequência didática, tal como proposto por Dolz et al. (2004), para trabalhar com os alunos a expressão oral e escrita, visto que tais esquemas viabilizariam a realização de duas produções de texto ao longo do trabalho didático, uma no início e outra no final, assim conforme sugerem esses autores. Além disso, sinalizam para a atuação da professora Clarice como mediadora, parceira, interlocutora, leitora primeira e privilegiada das produções dos seus alunos que, como tal, intervém nos textos no decorrer da escrita, concordando, discordando, acrescentando ou questionando o que foi escrito.

Por fim, observamos quatro esquemas voltados para a fase pós-produção de texto:

Quadro 3. Esquemas relacionados ao ensino da produção textual voltados para depois da escrita

\begin{tabular}{|c|c|c|c|}
\hline Esquema & Objetivo didático & Regra de ação & Teorema em ação \\
\hline $\begin{array}{l}\text { Promover a socia- } \\
\text { lização dos textos } \\
\text { produzidos pelos } \\
\text { alunos }\end{array}$ & $\begin{array}{l}\text { Valorizar a autoria } \\
\text { dos alunos. }\end{array}$ & $\begin{array}{l}\text { A forma de so- } \\
\text { cialização varia, } \\
\text { dependendo do } \\
\text { gênero textual } \\
\text { e das dinâmicas } \\
\text { próprias da sala } \\
\text { de aula. Na se- } \\
\text { quência didática } \\
\text { observada, foram } \\
\text { identificadas duas } \\
\text { formas: } \\
\text { a) leitura de al- } \\
\text { guns textos pro- } \\
\text { duzidos, realizada } \\
\text { em sala de aula e } \\
\text { em voz alta por } \\
\text { alguns alunos vo- } \\
\text { luntários; } \\
\text { b) exposição de } \\
\text { todos os textos } \\
\text { produzidos em } \\
\text { um mural num } \\
\text { corredor da esco- } \\
\text { la. }\end{array}$ & $\begin{array}{l}\text { Eles produzem e que- } \\
\text { rem ser valorizados pela } \\
\text { produção deles. } \\
\text { Porque a gente sempre } \\
\text { está construindo coleti- } \\
\text { vamente a aula. }\end{array}$ \\
\hline
\end{tabular}




\begin{tabular}{|c|c|c|c|}
\hline $\begin{array}{l}\text { Aproveitar as crí- } \\
\text { ticas dos alunos } \\
\text { sobre os textos } \\
\text { dos colegas para } \\
\text { trabalhar o gênero } \\
\text { textual }\end{array}$ & $\begin{array}{l}\text { Trabalhar o gênero } \\
\text { textual, fazendo os } \\
\text { alunos pensarem so- } \\
\text { bre ele. } \\
\text { Mostrar que a es- } \\
\text { tratégia presente no } \\
\text { texto não pode ser } \\
\text { usada em certos con- } \\
\text { textos, mas pode em } \\
\text { outros. }\end{array}$ & $\begin{array}{l}\text { Retoma as ques- } \\
\text { tões levantadas } \\
\text { pelos alunos du- } \\
\text { rante a discussão } \\
\text { coletiva sobre os } \\
\text { textos produzi- } \\
\text { dos pelos colegas, } \\
\text { verifica se fazem } \\
\text { sentido e articu- } \\
\text { la-as com o que } \\
\text { está sendo traba- } \\
\text { lhado sobre o gê- } \\
\text { nero. }\end{array}$ & $\begin{array}{l}\text { Então, tentar fazer tam- } \\
\text { bém essas relações e } \\
\text { não perder o que o alu- } \\
\text { no produziu de tudo. }\end{array}$ \\
\hline $\begin{array}{l}\text { Fazer retomadas } \\
\text { dos textos produ- } \\
\text { zidos pelos alu- } \\
\text { nos no decorrer } \\
\text { da sequência para } \\
\text { trabalhar aspectos } \\
\text { específicos do gê- } \\
\text { nero }\end{array}$ & $\begin{array}{l}\text { Trabalhar o gênero } \\
\text { textual, fazendo os } \\
\text { alunos pensarem so- } \\
\text { bre ele. } \\
\text { Preparar os alunos } \\
\text { para a revisão e faci- } \\
\text { litar a reescrita. } \\
\text { Ajudar os alunos a } \\
\text { obterem exemplos } \\
\text { que possam ser utili- } \\
\text { zados nos seus próxi- } \\
\text { mos textos. }\end{array}$ & $\begin{array}{l}\text { Durante a se- } \\
\text { quência, apresen- } \\
\text { ta em slides alguns } \\
\text { trechos dos textos } \\
\text { produzidos pelos } \\
\text { alunos na situa- } \\
\text { ção inicial e os } \\
\text { submete à apre- } \\
\text { ciação coletiva } \\
\text { pela turma (mas } \\
\text { sem explicitar de } \\
\text { quem era o texto) } \\
\text { para abordar as- } \\
\text { pectos específicos } \\
\text { do gênero que, de } \\
\text { acordo com as } \\
\text { produções, ainda } \\
\text { precisavam ser } \\
\text { aprendidos por } \\
\text { eles. Faz retoma- } \\
\text { da de apenas al- } \\
\text { guns dos textos } \\
\text { produzidos pelos } \\
\text { alunos e não de } \\
\text { todos os detalhes } \\
\text { do texto. }\end{array}$ & $\begin{array}{l}\text { Fica mais fácil para os } \\
\text { alunos fazerem a rees- } \\
\text { crita quando lembram } \\
\text { aquilo que a gente havia } \\
\text { sinalizado que precisava } \\
\text { colocar no texto. } \\
\text { Eu não vou retomar to- } \\
\text { dos os elementos, de } \\
\text { todos os textos, porque } \\
\text { não tenho condições } \\
\text { de fazer isso em sala de } \\
\text { aula. Então, de acordo } \\
\text { com o que eu estou tra- } \\
\text { balhando, eu vou focar } \\
\text { naquela produção que } \\
\text { eu vejo que vai contri- } \\
\text { buir diretamente com } \\
\text { a discussão de sala de } \\
\text { aula. }\end{array}$ \\
\hline
\end{tabular}




\begin{tabular}{|c|c|c|c|}
\hline $\begin{array}{l}\text { Confrontar textos } \\
\text { produzidos pelos } \\
\text { alunos }\end{array}$ & $\begin{array}{l}\text { Trabalhar o gênero } \\
\text { textual, fazendo os } \\
\text { alunos pensarem so- } \\
\text { bre ele. } \\
\text { Preparar os alunos } \\
\text { para a revisão e faci- } \\
\text { litar a reescrita. } \\
\text { Ajudar os alunos a } \\
\text { obterem exemplos } \\
\text { que possam ser utili- } \\
\text { zados nos seus próxi- } \\
\text { mos textos. }\end{array}$ & $\begin{array}{l}\text { Confronta os tex- } \\
\text { tos produzidos } \\
\text { pelos alunos em } \\
\text { relação a deter- } \\
\text { minados aspec- } \\
\text { tos do gênero, } \\
\text { fazendo-os refle- } \\
\text { tir sobre qual das } \\
\text { formas funciona } \\
\text { melhor e por quê. }\end{array}$ & $\begin{array}{l}\text { Quando a gente coloca } \\
\text { dois textos para compa- } \\
\text { rar, a gente faz com que } \\
\text { os alunos pensem sobre } \\
\text { a sua própria produção. } \\
\text { Então, quem já sabia vai } \\
\text { atestar que estava no } \\
\text { caminho certo e quem } \\
\text { ainda não sabia vai ver } \\
\text { que existem outras pos- } \\
\text { sibilidades mais ade- } \\
\text { quadas. }\end{array}$ \\
\hline
\end{tabular}

Fonte: As autoras.

Notamos que a professora se utilizou desses esquemas para estender o momento da produção textual às aulas seguintes e aproveitar os textos dos alunos para promover novas aprendizagens sobre a escrita e sobre o gênero textual em foco. Nesse sentido, concluímos que os esquemas acima apresentados têm por pressuposto a ideia de que, para ajudar seus alunos a desenvolver suas competências de escrita, a professora precisa levá-los não apenas a vivenciar atividades de produção de texto propriamente ditas, mas também a realizar exercícios que promovam reflexões específicas e sistemáticas sobre as especificidades da modalidade escrita da língua. Para tanto, a avaliação é um dos instrumentos que a professora utiliza, durante o processo de produção textual, para oportunizar o aprendizado, pelos alunos, por exemplo, dos elementos específicos do gênero, na medida em que, a partir dos textos produzidos por seus alunos, ela seleciona, conforme as prioridades estabelecidas, os elementos que precisam ser trabalhados e, com base nessa seleção, (re) orienta seu trabalho, adotando as estratégias didáticas mais adequadas para trabalhar os problemas evidenciados.

A seguir analisaremos duas cenas protagonizadas pela professora Clarice. A cena 1 diz respeito a um trecho de aula que foi exibido para ela no segundo encontro de autoconfrontação e que se refere ao início do quarto dia de aula. Para uma melhor compreensão do que acontece nessa aula, é necessário contextualizá-la. No segundo dia de aula, a professora solicitou aos alunos uma produção inicial, referente à escrita (individual, a ser desenvolvida em casa) de notícias sobre a realização iminente da exposição "Cenas de Leitura”. Essas notícias seriam publicadas no jornal da escola, intitulado "Cap \& Tal”.

\footnotetext{
4 "Cenas de Leitura" foi um projeto realizado pela professora Clarice com as suas duas turmas de $6^{\circ}$ ano no qual os alunos tiraram fotos (em pequenos grupos) que retratassem como e onde costumavam ler e criaram legendas para elas. Os resultados desse projeto seriam expostos na Feira da Leitura da escola, que aconteceria em breve.
} 
No terceiro dia de aula, a professora recolheu as notícias produzidas e promoveu a socialização de algumas através da leitura em voz alta por dois alunos. No quarto dia, voltou a promover a leitura em voz alta das notícias produzidas, dessa vez por cinco alunos. $\mathrm{O}$ trecho de aula abaixo diz respeito a uma parte dessa atividade de socialização (leitura feita por dois alunos):

\section{Cena 1}

PROFESSORA: Na aula passada, algumas pessoas ficaram de me entregar a produção de texto do "Cenas de Leitura", que era a exposição experimental, e aí eu estou recolhendo agora. É... Jorge, tu pode recolher? E, aí, vocês dois querem fazer a leitura, né?

ALUNO: Professora, eu pedi!

PROFESSORA: Você faz também. Vamos lá, rapidamente, os três vão ler.

ALUNA: Professora! Professora! O meu já tá aí!

PROFESSORA: Já tá aí, tá certo. Ó, Ana também quer ler, é? Bora lá! [...] Eu quero que todo mundo preste atenção. Bora lá! [...] Vamos lá! Eles vão fazer a leitura e a gente escuta e também, ó, na hora que eles estão lendo, é importante que vocês comparem com a produção de vocês. Será que eu escrevi parecido com o texto dos meus colegas? O que é que ele fez que eu não fiz? O que é que eu fiz que ele poderia ter feito? Esse é um momento também de reflexão sobre o que dizer no momento de relatar um fato. Vai, Manuel.

MANUEL: "1a Expoleitura do CAp. Os $6^{\text {os }}$ anos de 2017 produzem a 1a Feira de Leitura do CAp. O que será? O CAp receberá a sua $1^{\text {a }}$ Feira de Leitura, ou Expoleitura de 2017, que, de acordo com a professora Clarice Lispector" [...].

Uma aluna interrompe a leitura para falar com a professora em particular.

MANUEL: Uma coisa que eu achei que não ficou bem claro nos dois primeiros textos [inaudível] foram o título e depois o subtítulo. É... "isso de acordo com a professora Clarice Lispector, da disciplina de português. Mas os alunos do colégio [inaudível] mas, por que será? Para descobrir, [inaudível] Só vi um aluno, Manuel Bandeira, era um aluno do $6^{\circ}$ ano, ou seja, um dos participantes diretos da feira. Perguntei sobre a Expoleitura com a corrente opinião dos alunos que participariam da exposição. $\mathrm{O}$ aluno respondeu com as seguintes palavras: 'A feira, basicamente, consiste da leitura, onde será montado um mural de fotos com diferentes maneiras de se ler. Estou bem ansioso e animado [inaudível] a leitura discente. Sobre a opinião, bem, eu tenho o hábito de ler em casa, mas, é assim, não é bem a $1^{\text {a }}$ Expoleitura, pois temos lido em diversos momentos, e os alunos leem de diversas maneiras, isso acaba incentivando a gente a ler da nossa maneira e isso acaba tirando esse peso da 1a Expoleitura no CAp. Esse foi o depoimento de Manuel Bandeira. Você não pode, então, perder essa exposição. Você poderia ler do seu jeito [inaudível]”. Aí tem a foto [mostrando o texto e apontando para a foto].

PROFESSORA: Aham. Legal. Ó, vejam só: vocês vão fazer uma leitura rápida e, depois, a turma pode comentar, tá? Então, vão anotando, vocês que estão ouvindo; anotem pontos que poderiam sinalizar a respeito dos textos lidos, ok? Manuel, presta atenção. Anotem. Anotaram? 


\section{ALUNA: Anotar o quê?}

PROFESSORA: Pontos para comentar a respeito dos textos lidos. Cecília. Vá rápido. Vá, Cecília!

CECÍLIA: "CAp e Tal. Cenas de Leitura no CAp. Isso mesmo, pessoal. Nesse sábado, dia 21 de outubro, ocorrerá a exposição ‘Cenas de Leitura' aqui mesmo no Colégio de Aplicação. Esta exposição...” Daí dá pra ouvir?

PROFESSORA: Dá.

ALUNA: Dá pra ouvir, mas tu fala um pouquinho mais devagar!

PROFESSORA: Fala alto e um pouquinho mais devagar.

CECÍLIA: Vamos lá... "Esta exposição mostrará as fotos e legendas produzidas pelos $6^{\circ s}$ anos com o tema de leitura. O evento será organizado pela professora de português, Clarice Lispector. As fotografias foram feitas como trabalho avaliativo da sua matéria. Fique agora com uma das fotografias que um grupo fez". Aí, foi a gente que fez...

PROFESSORA: ... a fotografia...

CECÍLIA: ... foi que eu, ALUNA 1 e ALUNA 2 que fez. "os livros são frutos da imaginação" [inaudível].

PROFESSORA: Ok, vejam que houve uma diferença entre os dois textos, né? É... Manuel... Eu vou logo comentando um pouquinho pra gente não se perder tanto. É... Manuel, em relação a Cecília, colocou depoimentos, não é? E Cecília foi um pouco mais resumida, mas, mesmo assim, conseguiu trazer as informações básicas. Quer falar, Ana? Diga.

ANA: Tem uma coisa no texto que eu fiquei com uma dúvida. É a primeira exposição de "Cenas de Leitura", especificamente, mas é a primeira exposição do Colégio [inaudível]?

PROFESSORA: Não.

MANUEL: Não, foi por isso que eu falei "Expoleitura".

ANA: [inaudível] sobre exposição "Cenas de Leitura" [inaudível] exposição de leitura, no caso, pode ser qualquer leitura, e não só "Cenas de Leitura”...

PROFESSORA: Aham. Então, ela tá chamando atenção pra um conteúdo...

MANUEL: Não precisa ser verídico, podia ser fictício, né?

PROFESSORA: É, vejam só, o que é que eu sinto nos dois textos: uma presença muito forte da subjetividade e do envolvimento emocional com o conteúdo que tá sendo relatado... "Venham ver!" "Vai ter uma exposição"... E, assim, como se tivesse se envolvendo muito no tema. $\mathrm{O}$ repórter, ele tenta ser um pouco mais objetivo e aí a gente vai dar, depois, algumas dicas em relação a isso. É... os outros... Lins...

Fonte: As autoras.

Nesse trecho de aula, a professora coloca em prática o esquema promover a socialização dos textos produzidos pelos alunos a pedido deles próprios. Nessa ocasião, especificamente, a socialização se deu através da leitura em voz alta pelos estudantes dos seus textos para os colegas em sala de aula. Antes de iniciar as leituras, a professora dá as seguintes 
orientações: pede para que todos escutem e prestem atenção na leitura, para comparar as produções dos colegas com as suas e para que anotem pontos a respeito dos textos lidos para depois comentar. Assim, Clarice transforma o momento de socialização dos textos também num espaço de reflexão sobre as possibilidades de escrita. Após a leitura dos textos, a professora tece comentários sobre os dois textos lidos, comparando-os, e tentando pontuar o que eles têm de diferente e semelhante. Em seguida, abre espaço para os alunos comentarem, mediando e sistematizando a discussão. Na sequência, mais três alunos leem seus textos, e a professora procede da mesma maneira.

A cena 2, por sua vez, diz respeito ao comentário feito pela professora Clarice logo depois de assistir à cena 1 . Na cena 2 , ao ser questionada se isso faz parte da sua rotina e qual foi a sua intenção ao promover essa atividade, a docente nos explicita um dos seus esquemas:

\section{Cena 2}

Se isso faz parte da rotina? Faz. A gente sempre tem um momento de socialização da produção de texto dos alunos, não é? Seja nessa primeira versão ou então, às vezes, eu coloco pra última versão do texto. Não é? Então, nesse momento eles fizeram a socialização da notícia e eu sempre pergunto: “Alguém quer ler?” E aí eu estava esperando que somente dois fossem ler, porque já tinha havido a socialização na aula anterior, então, hoje eu não iria fazer a socialização, mas eles ficam insistindo, inclusive Cecília, que foi a última que entrou, ficou: "Não, mas eu já tinha dito na aula passada que iria, não sei o quê...”, aí eu: “Tá bom, vai” [risos]. Acabou que eu fico, às vezes, em determinadas circunstâncias, até nervosa porque eu tenho que dar seguimento ao que eu tinha planejado, né, eu pensei no máximo uma ou duas pessoas, mas vieram cinco, eles querem participar, porque eles se sentem já acolhidos nessa sistemática, né, então eles produzem e querem ser valorizados pela produção deles e pra mim isso é importante, né, porque a gente sempre tá construindo coletivamente a aula, como eu tinha dito em outra oportunidade, não é? Então, isso faz parte da rotina, de fazer a socialização, né, ou na primeira versão do texto ou na última versão do texto, agora a última versão do texto, a socialização, muitas vezes, ela já é, por exemplo, publicada, não necessariamente lida por todo mundo, vai depender do gênero textual e de como é que a gente montou esse projeto didático, não é? Então, por exemplo, esse último texto que eles vão fazer, a socialização vai ser uma exposição. E aí vai ficar, né, à disposição tanto dos alunos da sala, quanto de outros alunos, a leitura, né? [...] E aí, qual foi a intenção ao promover... a intenção foi justamente deles poderem ter valorizada a sua autoria, a sua voz na sala de aula, eles trazerem pra compartilhar junto com os colegas não só o texto, mas também o que eles sabem sobre a produção de texto, o que eles produzirem aí, os outros também poderem pensar sobre as estratégias que foram utilizadas, se aquela estratégia tá adequada ou não, para que contexto está adequada aquela estratégia [...].

\section{Fonte: As autoras.}


Nesse trecho, a professora explicitou as regras de ação que utilizou para colocar em prática o esquema promover a socialização dos textos produzidos pelos alunos. Primeiramente, ela informou que sempre se preocupa em socializar os textos produzidos pelos alunos, mas que a forma de socialização varia, dependendo do gênero textual e das dinâmicas próprias da sala de aula. Nesse caso, a regra de ação escolhida para socializar as produções iniciais de notícia foi: leitura de alguns textos produzidos, realizada em sala de aula e em voz alta por alguns alunos voluntários. Todavia, na sequência didática observada também identificamos outra forma, colocada em prática para a socialização das produções finais: exposição de todos os textos produzidos em um mural num corredor da escola.

Da mesma forma, a docente esclareceu qual foi o seu objetivo ao realizar tal procedimento. A esse respeito, a professora Clarice explicita que teve como intuito valorizar a autoria dos alunos. Esse objetivo, almejado pela professora, relaciona-se diretamente com um dos teoremas em ação explicitados por ela no encontro de autoconfrontação: a ideia de que os alunos produzem e querem ser valorizados pela produção deles. Assim, por acreditar que seus alunos, quando produzem algum material, anseiam pela valorização não só do produto final, mas do seu trabalho como um todo, Clarice se esforça para promover seu compartilhamento e garantir o cumprimento do seu objetivo. Ademais, o cuidado da professora de sempre garantir a socialização dos textos produzidos pelos seus alunos está pautado, segundo ela, também em outro pressuposto, já mencionado anteriormente ao discutirmos sobre outro esquema: a ideia de que "a gente sempre está construindo coletivamente a aula”. Assim, na medida em que a aula não acontece apenas a partir do professor, mas requer a atuação conjunta entre ele e a turma, reforça-se a preocupação da docente em fazer o aluno participar ativamente da aula e interagir com todos, lendo seus textos, comentando os dos colegas e discutindo com a professora.

A partir da análise dessas duas cenas, pudemos ratificar o quanto a tríade "objetivo, regra de ação e teorema em ação" é, de fato, constitutiva do esquema. Assim, a ação rotineira da professora parece estar ancorada num conjunto elementos que lhe permitem agir com segurança e de forma eficaz.

Por fim, ao analisar os esquemas, observamos que alguns deles são comumente utilizados pelos professores de Língua Portuguesa em geral ao ensinar a produção de texto como, por exemplo: propor temas cotidianos para as produções de textos, receber os alunos no birô para tirar dúvidas sobre a produção de texto e promover a socialização dos textos produzidos pelos alunos. Diante disso, concluímos que Clarice faz uso de um repertório de esquemas socialmente construídos ao longo da história no seu meio profis- 
sional e partilhados atualmente por todo um coletivo de docentes de Língua Portuguesa. Assim, podemos afirmar que a competência profissional individual desta professora também está ancorada numa cultura profissional coletiva.

\section{Considerações finais}

Durante os encontros de autoconfrontação, Clarice falou sobre alguns dos seus esquemas relacionados à elaboração de textos (antes, durante e depois da escrita). Conseguimos, através de nossa pesquisa, fazer um levantamento de variados e inventivos procedimentos utilizados por esta professora experiente para ensinar seus alunos a produzirem textos, tendo como base uma perspectiva sociointeracionista, tais como apresentar e discutir as condições de produção do texto, promover a socialização dos textos produzidos pelos alunos e promover a apreciação e avaliação oral e coletiva pela turma dos textos produzidos pelos alunos.

Tal perspectiva de ensino é relativamente recente (emergiu na segunda metade dos anos 1980) e permanece em construção. Por isso, as estratégias didáticas para a sua concretização não estão consolidadas e colocá-las em prática ainda representa um desafio para muitos professores. Dessa forma, ao fazer uma descrição de alguns esquemas típicos de uma prática efetivamente sociointeracionista, este trabalho pode ajudar na compreensão de como seria ensinar Língua Portuguesa (e mais especificamente a produção de textos) dentro dessa nova perspectiva e, assim, contribuir para a formação de novos professores abertos à renovação de suas práticas e experiências. Ademais, esta pesquisa aponta para a importância de continuarmos a realizar pesquisas que tenham como objeto de estudo exitosas e inovadoras práticas de ensino de Língua Portuguesa nos anos finais do ensino fundamental, buscando compreender suas várias determinações e significados. É nosso anseio que tais pesquisas apontem caminhos possíveis para o desenvolvimento e multiplicação de boas práticas de ensino de produção de texto na escola básica.

\section{Referências}

BUNZEN, Clécio dos Santos. Da era da composição à era dos gêneros: o ensino de produção de texto no ensino médio. In: BUNZEN, Clecio; MENDONÇA. Márcia. (orgs.) Português no Ensino Médio e Formação do Professor. São Paulo: Parábola Editorial, 2006, p. 139-162.

CLOT, Yves. A Função Psicológica do Trabalho. Petrópolis/RJ: Vozes, 2007.

CLOT, Yves. Trabalho e poder de agir. Belo Horizonte: Fabrefactum, 2010.

COSTA VAL, Maria da Graça; VIEIRA, Martha Lourenço. Produção de textos escritos: construção de espaços de interlocução. Belo Horizonte: Ceale/FaE/UFMG, 2005. 
DOLZ, Joaquim et al. Sequências didáticas para o oral e a escrita: apresentação de um procedimento. In: ROJO, Roxane; CORDEIRO, Glaís Sales (trad. e org.). Gêneros orais e escritos na escola. Campinas/SP: Mercado de Letras, 2004, p. 95-128.

DOLZ, Joaquim; SCHNEUWLY, Bernard. Os gêneros escolares - das práticas de linguagem aos objetos de ensino. In: ROJO, Roxane; CORDEIRO, Glaís Sales (trad. e org.). Gêneros orais e escritos na escola. Campinas/SP: Mercado de Letras, 2004, p. 71-94.

GOIGOUX, Roland. Lector in didactica: Un cadre théorique pour l'étude de l'activité du maître de lecture. In: BERNIÉ, Jean-Paul (org.). Apprentissage, Développement et significations. Presses Universitaires de France, 2001, p. 129-153.

GOIGOUX, Roland. Analyser l'activité d'enseignement de la lecture: une monographie. Revue Française de Pédagogie, n. 138 - Janvier-Février-Mars, 2002, p. 125-134.

GOIGOUX, Roland. Un modèle d'analyse de l'activité des enseignants. Education \& Didactique, 2007, vol 1, n. 3, p. 47-70.

GOIGOUX, Roland; VERGNAUD, Gérard. Schèmes professionnels. Revue de l'association internationale de recherches en didactique du français, AiRDF, 2005, 36, p. 7-10.

LEAL, Telma Ferraz; MELO, Kátia Leal Reis de. Produção de textos: introdução ao tema. In: LEAL, Telma Ferraz; BRANDÃO, Ana Carolina Perrusi (Orgs.) Produção de textos na escola: reflexões e práticas no Ensino Fundamental. Belo Horizonte: Autêntica, 2006, p. 11-28.

MENEGASSI, Renilson José; FUZA, Ângela Francine. Procedimentos de escrita em sala de aula do ensino fundamental. Revista Signótica, v. 20, n. 2, p. 471-495, jul./dez. 2008.

MOTTA-ROTH, Désirée. O ensino de produção textual com base em atividades sociais e gêneros textuais. Revista Linguagem em (Dis)curso - LemD, Tubarão, v. 6, n. 3, p. 495-517, set./dez. 2006.

OLIVEIRA, Maria Bernadete F. de. A produção do conhecimento no espaço escolar: considerações em torno da produção textual. Revista do GELNE, v. 2, n. 2, p. 1-3, 2000.

PIMENTA, Selma Garrido. Pesquisa-ação crítico-colaborativa: construindo seu significado a partir de experiências com a formação docente. Educação e Pesquisa, São Paulo, v. 31, n. 3, p. 521-539, set./dez. 2005.

SANTOS, Leonor Werneck; TEIXEIRA, Claudia de Souza. Correção e avaliação de textos. In: COELHO, Fábio André; PALOMANES, Roza. (orgs.) Ensino de produção textual. São Paulo: Contexto, 2016, p. 23-41.

VOLOSHINOV, Valentin. Língua, fala e enunciação. In: Marxismo e filosofia da linguagem: problemas fundamentais do método sociológico na ciência da linguagem. 10. ed. São Paulo: Annablume, 2002, p. 90-109.

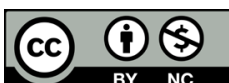

Submetido em: 07/02/2020

Aceito em: 20/03/2020 